\title{
Degradation of Herbicide Diuron in Water Employing the $\mathrm{Fe}^{0} / \mathrm{H}_{2} \mathrm{O}_{2}$ System
}

\author{
Liziara C. Cabrera, ${ }^{a}$ Sergiane S. Caldas, ${ }^{a}$ Sandra Rodrigues, ${ }^{b}$ Adalto Bianchini, ${ }^{b}$ \\ Fábio A. Duarte ${ }^{a}$ and Ednei G. Primel ${ }^{*, a}$
}

\author{
${ }^{a}$ Escola de Química e Alimentos and ${ }^{b}$ Instituto de Ciências Biológicas, \\ Universidade Federal do Rio Grande, CP 474, 96201-900 Rio Grande-RS, Brazil
}

\begin{abstract}
O sistema de degradação utilizando ferro metálico e peróxido de hidrogênio (reação de Fenton) foi empregado para a degradação do herbicida diurom. Visando obter as melhores condições de degradação, foram otimizados parâmetros que influenciam no processo, como $\mathrm{pH}$, concentração de peróxido de hidrogênio $\left(\mathrm{H}_{2} \mathrm{O}_{2}\right)$ e quantidade de ferro. A degradação do herbicida foi acompanhada por cromatografia líquida com detecção por arranjo de diodos (CLAE-DAD) e cromatografia líquida com detecção por espectrometria de massas sequencial (LC-ESI-MS/MS), além da determinação de carbono orgânico total (COT). Nas melhores condições de degradação, $\mathrm{pH}=2,5 ; 2 \mathrm{~g}$ de ferro e $2 \mathrm{mmol} \mathrm{L}^{-1}$ de $\mathrm{H}_{2} \mathrm{O}_{2}$, uma solução aquosa de diurom comercial $\left(10 \mathrm{mg} \mathrm{L}^{-1}\right)$, alcançou valores não detectáveis ao tempo de $10 \mathrm{~min}$, para diurom e para o metabólito monitorado, 3,4-DCA. Ainda os valores de COT foram reduzidos, chegando a valores menores que $5 \mathrm{mg} \mathrm{L}^{-1}$, mostrando a eficiência e rapidez do sistema.
\end{abstract}

A degradation system using metallic iron and hydrogen peroxide (Fenton reaction) was employed for the degradation of the diuron herbicide. In order to obtain the maximum degradation the main conditions such as $\mathrm{pH}$, hydrogen peroxide concentration and iron amount, were optimized. Herbicide degradation was evaluated by liquid chromatography with diode array detection (HPLC-DAD) and liquid chromatography tandem mass spectrometric detection (LC-ESI-MS/MS) and total organic carbon analysis (TOC). In the best degradation condition, $\mathrm{pH}=2.5,2 \mathrm{~g}$ of iron and $2 \mathrm{mmol} \mathrm{L}^{-1}$ of hydrogen peroxide, after $10 \mathrm{~min}$ a commercial diuron solution $\left(10 \mathrm{mg} \mathrm{L}^{-1}\right)$ had no detection values for diuron and its metabolic, 3,4-dichloroaniline (3,4-DCA). The TOC was reduced to values lower than $5 \mathrm{mg} \mathrm{L}^{-1}$ showing the efficiency of the system.

Keywords: diuron, Fenton, degradation, 3,4-DCA, water

\section{Introduction}

Nowadays herbicides are indispensable for agricultural practices. Nevertheless, herbicides also represent a risk factor for the water quality because these substances are generally toxic and nonbiodegradable. Apart from lixiviates coming from agricultural fields, the washing of herbicide containers and the lack of treatment for the solutions also contribute to this problem, producing highly polluted effluents that should be treated before their disposal in the environment. ${ }^{1}$

Diuron ( $N$-(3,4-dichlorophenyl)- $N, N$-dimethyl-urea) is an herbicide which belongs to the phenylamide family and to the subclass phenylurea. It represents an important class of contact herbicides that have been used worldwide

\footnotetext{
*e-mail: eprimelfurg@gmail.com
}

for more than 40 years. $^{2}$ It inhibits the photosynthesis by preventing oxygen production, and blocks the electron transfer at the level of photosystem II of photosynthetic micro-organisms and plants. Therefore, diuron has been used to control a wide variety of annual and perennial broadleaf and grassy weeds as well as mosses. It has also been used on non-crop areas such as roads, garden paths, and on many agricultural crops such as fruit, cotton, sugar cane and wheat. ${ }^{3}$ Moreover, diuron has been used as an antifouling paint booster biocide. This is the reason for it has been found in the estuarine, coastal, lake waters and sediments. ${ }^{4-6}$ There are also several reports on diuron residues in the seawater and sand. ${ }^{4,7,8}$

In the region that this work was developed, diuron is used in agriculture, mainly in family farms, where it is said to be used to prepare the land before planting. Navigation is other very intense activity in this region, and diuron is 
used in antifouling paints. Thus, studies that propose the degradation of this compound have been contributing to the preservation of natural resources in this region.

Diuron is a non-ionic compound with moderate water solubility, about $36-42 \mathrm{mg} \mathrm{L}^{-1}$ at $20-25^{\circ} \mathrm{C}$. It remains solid at ambient temperature with a melting point at $158-159^{\circ} \mathrm{C}$. Vapour pressure is $1.1 \times 10^{-3} \mathrm{mPa}$ at $25^{\circ} \mathrm{C}$ and the calculated Henry's law constant is $0.0012 \mathrm{~Pa} \mathrm{~m}^{3} \mathrm{~mol}^{-1}$, suggesting that diuron is not volatile compound in water or soil. ${ }^{9,10}$ Its hydrolysis rate is negligible at neutral $\mathrm{pH}$ but it increases as the conditions become strongly acidic or alkaline leading to its principal derivative, 3,4-dichloroaniline (3,4-DCA). ${ }^{11}$ It has a low to moderate octanol-water partition coefficient $\left(\log \mathrm{K}_{\mathrm{ow}} 2.85\right)$. This compound has a soil organic fraction partition constant $\left(\mathrm{K}_{\mathrm{oc}}\right)$ of 400 , which predicts its adsorption affinity to soil organic particles. ${ }^{12}$ Due to its high persistence $\left(t_{1 / 2}\right)$ in soil, from one month to one year, diuron can be found in many environments such as soil, sediments and water. ${ }^{5,9}$ In soil, considering its low volatility and its high $\mathrm{K}_{\mathrm{oc}}$, diuron is found in the solid phase rather than in the gaseous or liquid phase. Absorption studies of diuron have shown that the proportion of organic matter in soil directly influences the amount of adsorbed diuron. ${ }^{3}$ It is also slightly toxic to mammals and birds as well as moderately toxic to aquatic invertebrates. Besides, the principal product of biodegradation 3,4-DCA exhibits a higher toxicity and is also persistent in soil, water and groundwater. Thus, diuron indirectly and directly possesses a significant amount of toxicity and could be a potential poisoning pesticide contaminant. $^{3}$

Some effluent treatments prevent diuron and its metabolites from reaching the environment. However, a classical biological treatment is not compatible due to its toxicity regarding microorganisms involved in these processes, ${ }^{6}$ therefore, other treatments are necessary. In this sense, advanced oxidation processes (AOPs) are among the most widely used technologies for industrial effluent treatment of water polluted by organic compounds characterized by their high chemical stability and low biodegradability.

Advanced oxidation processes are based on the production of the highly reactive hydroxyl radical $(\mathrm{OH} \bullet)$ that react with organic matter (redox standard potential $2.8 \mathrm{~V}$ ) under mild experimental conditions. Due to the reactivity of free hydroxyl radicals, the attack is non selective, a fact that is useful for the treatment of wastewater containing many different pollutants. Among the AOPs, the Fenton process has been used because it is a simple, efficient and inexpensive process. The Fenton's reagent is composed by a solution containing hydrogen peroxide and iron ions in an acidic medium, producing carbonic oxide
$\left(\mathrm{CO}_{2}\right)$ and water as final products and, sometimes, other intermediate metabolites.

The Fenton process has been used for degradation of several organic compounds. ${ }^{13-16}$ It has also been used for pesticide degradation in the last years. ${ }^{17-19}$ Diuron degradation has been studied by different processes such as photo-Fenton, photocatalytic and biodegradability experiments and microbiologycal degradation. ${ }^{15-21}$

Zero-valent iron has been used to be an effective material for the removal of a variety of important organic contaminants from water. ${ }^{17,22,23}$ The redox couple formed by zero-valent iron $\left(\mathrm{Fe}^{0}\right)$ and dissolved aqueous $\mathrm{Fe}^{2+}$ has a standard reduction potential of $-0.440 \mathrm{~V} .{ }^{24}$ This makes $\mathrm{Fe}^{0} \mathrm{a}$ reducing agent for many redox-labile substances, including hydrogen ions, carbonate, sulfate, nitrate and oxygen. ${ }^{18,24-26}$

The aim of this study was to optimize, develop and implement a simple, cheap and efficient method for diuron residue degradation. The method optimization was performed to obtain the best condition for $\mathrm{pH}$, Fe amount and hydrogen peroxide concentration. Degradation performance was followed by HPLC-DAD, LC-ESI-MS/MS and TOC analysis.

\section{Experimental}

\section{Reagents}

Diuron and 3,4-DCA analytical standard were supplied by Sigma Aldrich (São Paulo, Brazil) and methanol (HPLC grade) was supplied by Mallinckrodt Baker (Phillisburg, NJ, USA). Water used for all aqueous solutions was purified by an ultrapure water purification system Direct Q3 (resistibility 18.2 $\mathrm{M} \Omega \mathrm{cm}$ ) by Millipore (Bedford, MA, USA).

Individual stock solution containing $1000 \mathrm{mg} \mathrm{L}^{-1}$ of the target compounds were prepared in methanol and stored at $-18{ }^{\circ} \mathrm{C}$. Two working standard containing $100 \mathrm{mg} \mathrm{L}^{-1}$ of each compound were prepared in methanol. This working standard was used to prepare successive dilutions in order to carry out the analytical curve for HPLC-DAD and LC-ESI-MS/MS analysis.

Phosphoric acid (85\%) of analytical grade and hydrogen peroxide were provided by Merck (Darmstadt, Germany). Degradation experiment was performed using a commercial steel straw (as iron font) and a commercial diuron $500 \mathrm{SC}$ solution (purchased by Nortox, $500 \mathrm{~g} \mathrm{~L}^{-1}$ ).

\section{HPLC-DAD analysis}

Separation was performed using an HPLC apparatus consisting of a column Spherisorb ODS2 $5 \mu \mathrm{m} 80 \AA$ $(150 \times 4.6 \mathrm{~mm})$, from Waters, a Waters 600 pump model, 
associated with a Waters 2996 Photodiode Array Detector, Rheodyne $20 \mu \mathrm{L}$ loop injector, connected to an Empower PDA software for data acquisition. The analytical column was conditioned by passing the mobile phase through it

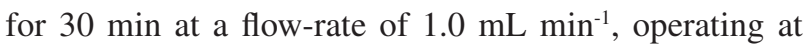
ambient temperature. The flow-rate was set at $1.0 \mathrm{~mL} \mathrm{~min}^{-1}$ and quantification was carried out with DAD detection at $244 \mathrm{~nm}$. The mobile phase composition was methanol:water (70:30, v/v). The mobile phases were degassed for $30 \mathrm{~min}$ in an ultrasonic bath before use.

Instrument calibration was performed using seven different concentrations $(0.03 ; 0.3 ; 0.6 ; 1.25 ; 2.5 ; 5$; $10 \mathrm{mg} \mathrm{L}^{-1}$ ) of the pesticide mixture containing diuron and 3,4-DCA. Each mixed standard solution was analyzed in three replicates. The limit of detection (LOD) and the limit of quantification (LOQ) of the method were calculated as three and nine times, respectively, the standard deviation of the response of ten independent replicates of blank samples. The LOQ was the first point of calibration curve.

\section{LC-ESI-MS/MS analysis}

Liquid chromatography with mass spectrometric detection was performed in a Waters Alliance 2695 Separations Module fitted with an autosampler, a membrane degasser and a quaternary pump. Mass spectrometry was performed on a Micromass Quattro Micro API with an ESI interface. The LC separation was carried out in an XTerra analytical column $(50 \times 3 \mathrm{~mm}$, i.d. $3.5 \mu \mathrm{m})$ (Waters, Milford, MA, USA). Analytical instrument control, data acquisition and treatment were performed by software Masslynx version 4.1, 2005 (Waters, Milford, MA, USA).

A sample volume of $20 \mu \mathrm{L}$ was injected by an autosampler. The mobile phase was methanol:water (70:30, v/v), at a constant flow-rate of $0.3 \mathrm{~mL} \mathrm{~min}{ }^{-1}$. Parameters were optimized by continuous infusion of a standard solution $\left(1000 \mu \mathrm{g} \mathrm{L}^{-1}\right)$ with a syringe pump with flow-rate at $10 \mu \mathrm{L} \mathrm{min}{ }^{-1}$. Ionization of the compounds was studied using ESI interface in the positive (PI) and negative (NI) ionization modes. The mass spectrometer was operated in scan, product ion scan and multiple reaction monitoring (MRM) modes. Typical interface conditions were optimized for maximum intensity of the precursor ions as follows: capillary voltage $3.5 \mathrm{kV}$; nebulizer and desolvation (drying gas) flow were set at 550 and $150 \mathrm{~L} \mathrm{~h}^{-1}$, respectively; source block and desolvation temperatures were 100 and $350{ }^{\circ} \mathrm{C}$, respectively. Nitrogen was used as nebulizing, desolvation and cone gas, and argon was used as collision gas.

To obtain the fragments that were monitored, firstly, direct infusions were performed in a mass spectrometer in full scan mode. In this mode, two fragments were selected for each compound. The most intense fragment was used for quantification.

Instrument calibration was performed using seven different concentrations $(1 ; 10 ; 100 ; 250 ; 500 ; 750$; $1000 \mu \mathrm{g} \mathrm{L}^{-1}$ ) of the diuron and 3,4-DCA mixture. LOD and LOQ of the method were obtained in the same way as the ones of the HPLC-DAD technique.

TOC

Total organic carbon (TOC) was measured in a TOC Analyzer (TOC, model TOC-V CPH, Shimadzu, Japan) using a non-purgeable organic carbon (NPOC) analysis.

\section{Degradation experiment}

A commercial diuron sample 50,000 times diluted (in ultrapure water) up to final concentration of $10 \mathrm{mg} \mathrm{L}^{-1}$, was used for all degradation experiments.

Experiments were carried out in a glass tube (about $1.5 \mathrm{~m}$ long, $1 \mathrm{~cm}$ i.d.) with iron wool inside, and the diluted commercial solution (after adding $\mathrm{H}_{2} \mathrm{O}_{2}$ and $\mathrm{H}_{3} \mathrm{PO}_{4}: \mathrm{H}_{2} \mathrm{O}$ $1: 1 \mathrm{v} / \mathrm{v}$ ) flowed through to the iron wool at $0.1 \mathrm{~L} \mathrm{~min}^{-1}$. For experiment optimization, $\mathrm{H}_{2} \mathrm{O}_{2}$ concentration, $\mathrm{pH}$ and $\mathrm{Fe}$ amount were evaluated in order to choose the best degradation condition. Initially, the $\mathrm{pH}$ values studied were $2.5 ; 3.5 ; 4.5$ and 8.5. After, $\mathrm{H}_{2} \mathrm{O}_{2}$ concentration was varied from 2 to $4 \mathrm{mmol} \mathrm{L}^{-1}$ in the best $\mathrm{pH}$ condition. After, $\mathrm{Fe}$ amount was evaluated from 1,2 and $3 \mathrm{~g}$ in the best $\mathrm{pH}$ and $\mathrm{H}_{2} \mathrm{O}_{2}$ concentration condition. Each condition was tested in triplicate.

Aliquots were collected before (with and without $\mathrm{pH}$ adjustment and with addition of $\mathrm{H}_{2} \mathrm{O}_{2}$ ) and during the experiment. Each aliquot was analyzed by HPLC-DAD and compounds confirmation was performed by LC-ESI-MS/MS. In addition, TOC was determined in all aliquots.

\section{Results and Discussion}

The efficiency of the $\mathrm{Fe}^{0} / \mathrm{H}_{2} \mathrm{O}_{2}$ system to promote the degradation of diuron was initialy investigated using HPLC-DAD and LC-ESI-MS/MS to monitor the disappearance of this compound.

\section{HPLC-DAD and LC-ESI-MS/MS analysis}

The identification of compounds in the sample was accomplished based on their retention times and by comparison of the UV-Vis spectrum of standard solutions and the UV-Vis spectrum of detected peak in the sample. The quantitative analysis was performed with external calibration by measurement of peak area. 
The diode array detector was set at $244 \mathrm{~nm}$ for both compounds, because it is the wavelength of the highest absorption. The time of analysis was $9 \mathrm{~min}$ and retention times were 5.3 and $7.0 \mathrm{~min}$, for 3,4-DCA and diuron, respectively.

For the LC-ESI-MS/MS the compounds showed more efficient ionization in the positive mode (PI). The retention times, precursor and product ion cone and collision voltages are shown in Table 1.

\section{Analytical parameters}

Diuron calibration curve was $\mathrm{y}=1.45 \times 10^{5} \mathrm{x}+1.03 \times 10^{4}$; $\mathrm{r}=0.999 ; 3$,4-DCA calibration curve was $\mathrm{y}=8.98 \times 10^{4} \mathrm{x}+$ $1.25 \times 10^{4} ; \mathrm{r}=0.999$. Instrument LOQ was $0.03 \mathrm{mg} \mathrm{L}^{-1}$ for both compounds in HPLC-DAD.

By LC-ESI-MS/MS the calibration curve was $\mathrm{y}=$ 646.666x $+1.623 ; \mathrm{r}=0.993$. Instrument LOQ was $1 \mu \mathrm{g} \mathrm{L} \mathrm{L}^{-1}$. For 3,4-DCA, the calibration curve was $\mathrm{y}=177.126 \mathrm{x}+$ 0.102; $\mathrm{r}=0.997$. Instrument LOQ was $1 \mu \mathrm{g} \mathrm{\textrm {L } ^ { - 1 }}$. Both technique showed reproducibility (RSD\%) among injection lower than $10 \%$.

\section{Degradation experiment}

The main mechanism of zero-valent iron degradation is based on the reduction of electron deficient centers. This process is dependent on electron transfer between heterogeneous phases and the surface area has an important effect on the reactivity. ${ }^{24,27-29}$ Since the degradation of diuron by $\mathrm{Fe}^{0}$ involves the reaction of metal surface, the superficial area has a strong influence in this process. Figure 1 shows the variation of the efficiency of diuron degradation with the increase of $\mathrm{Fe}^{0}$ amount.

In another study, the authors found similar results to those found in this work. In both cases, the concentration of iron and the increase of hydrogen peroxide concentration (Figure 2) improve the degradation efficiency up to a certain limit. On the other hand, their excess may promote the inefficiency of the process..$^{24,30}$

The $\mathrm{pH}$ effect on the degradation of diuron by $\mathrm{Fe}^{0}$ is presented in Figure 3. In acid solutions diuron degradation was efficient. The minimal dependence on the solution conditions contrasts favorably with the narrow optimal $\mathrm{pH}$ range normally observed for other treatment methods. ${ }^{31}$ The process was efficient over a broad $\mathrm{pH}$ range (between $\mathrm{pH} 2.5$ and 3.5). On the other hand, at higher $\mathrm{pH}$ values, an acute decrease on diuron degradation was observed, mainly

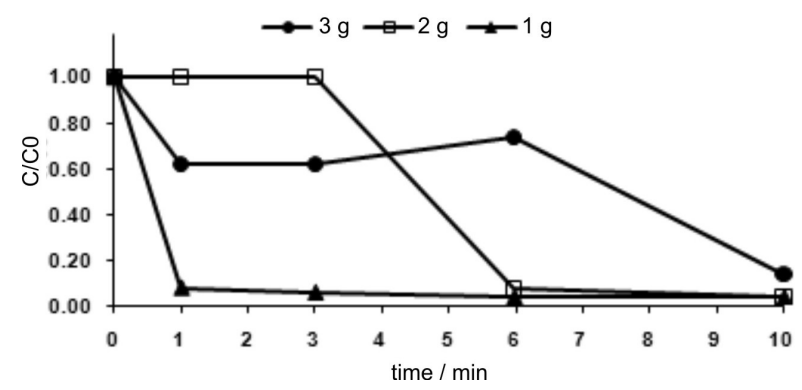

Figure 1. Variation in the efficiency of diuron degradation with the increase of $\mathrm{Fe}^{0}$ amount.

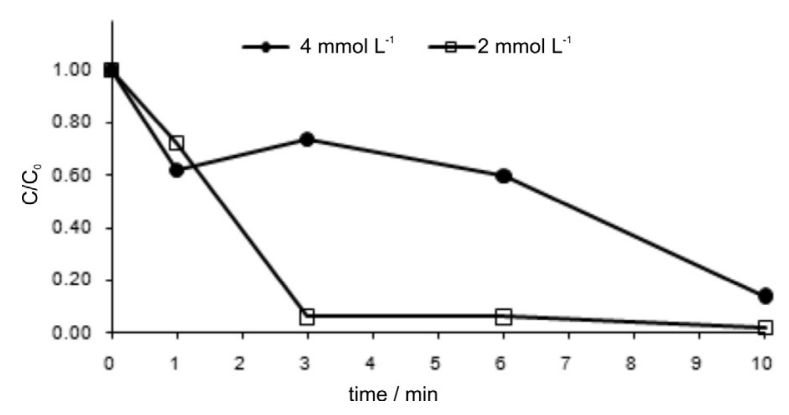

Figure 2. Variation in the efficiency of diuron degradation with the increase of $\mathrm{H}_{2} \mathrm{O}_{2}$ concentration.

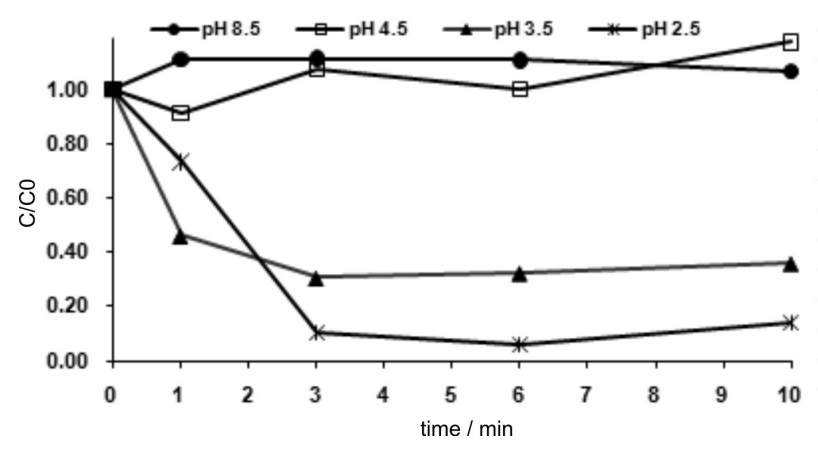

Figure 3. pH effect on the efficiency of diuron degradation.

Table 1. Retention times $\left(t_{\mathrm{R}}\right)$, MRM transitions and MS operating parameters selected for the analysis of diuron and 3,4-DCA by ESI in positive mode (dwell time $0.3 \mathrm{~s}$ )

\begin{tabular}{|c|c|c|c|c|c|c|}
\hline Pesticide & $\mathrm{t}_{\mathrm{R}}(\min )$ & $\mathrm{M}_{\mathrm{w}}^{\mathrm{a}}$ & $\begin{array}{c}\text { Precursor ion } \\
(\mathrm{m} / \mathrm{z})\end{array}$ & $\begin{array}{l}\text { Product ion } \\
(\mathrm{m} / \mathrm{z})\end{array}$ & $\begin{array}{c}\text { Cone voltage } \\
(\mathrm{V})\end{array}$ & $\begin{array}{c}\text { Collision Energy } \\
(\mathrm{eV})\end{array}$ \\
\hline \multirow[t]{2}{*}{ diuron } & 2.6 & 232 & 233 & 160 & 28 & 20 \\
\hline & & & & 72 & 28 & 25 \\
\hline \multirow[t]{2}{*}{ 3,4-DCA } & 2.4 & 161 & 162 & 127 & 35 & 20 \\
\hline & & & & 109 & 40 & 25 \\
\hline
\end{tabular}

${ }^{\mathrm{a}} \mathrm{M}_{\mathrm{w}}$ : molecular weight. 
due to the hydrolysis of iron ions and deposition of iron oxides on the $\mathrm{Fe}^{0}$ surface. The most effective degradation of diuron was observed at $\mathrm{pH} 2.5$ and this value was used for further experiments.

Previous studies ${ }^{22,24,27,29}$ have shown that $\mathrm{Fe}^{0}$ can oxidize organic compounds in the presence of oxygen. In this case, dissolved oxygen is the preferred iron oxidant, resulting in a rapid corrosion according to equation 1 .

$\mathrm{Fe}^{0}+\mathrm{O}_{2}+2 \mathrm{H}^{+} \rightleftharpoons \mathrm{Fe}^{2+}+\mathrm{H}_{2} \mathrm{O}_{2}$

In this study the initial step is showed in equation 2:

$\mathrm{Fe}^{0}+\mathrm{H}_{2} \mathrm{O}_{2} \rightleftharpoons \mathrm{Fe}^{2+}+\mathrm{OH} \bullet$

Where, $\mathrm{Fe}^{0}$ could cause the reduction of $\mathrm{H}_{2} \mathrm{O}_{2}$ to yield hydroxyl radicals. Additionally, $\mathrm{Fe}^{2+}$ can promote the subsequent reduction of $\mathrm{H}_{2} \mathrm{O}_{2}$ as showed in equation 3, one of most studied advanced oxidation processes (the Fenton's process) which has been widely employed for the efficient degradation and mineralization of a broad range of organic pollutant compounds. ${ }^{9,19}$

$\mathrm{Fe}^{2+}+\mathrm{H}_{2} \mathrm{O}_{2} \rightleftharpoons \mathrm{Fe}^{3+}+\mathrm{OH} \bullet+\mathrm{OH}^{-}$

Consequently, hydroxyl radical, one of the most potent oxidizing agents known ${ }^{7}$ can be formed and promote diuron mineralization via oxidation.

Evaluation of the diuron degradation by HPLC-DAD, LC-ESI-MS/MS and TOC analysis

Applying the best degradation conditions ( $\mathrm{pH} 2.5$; $2 \mathrm{~g}$ of iron and $2 \mathrm{mmol} \mathrm{L}^{-1} \mathrm{H}_{2} \mathrm{O}_{2}$ ) for a commercial diuron solution $\left(10 \mathrm{mg} \mathrm{L}^{-1}\right)$ no quantification values were observed (lower than $0.03 \mathrm{mg} \mathrm{L}^{-1}$ and $1 \mu \mathrm{g} \mathrm{L}^{-1}$ ) for diuron and 3,4-DCA after 10 min of treatment. The treatment showed an excellent potential for promoting degradation (higher than 99\%) of diuron and 3,4-DCA. The process also resulted in an excellent degree of effluent mineralization, with $c a$. $40 \%$ TOC removal in 10 min of treatment.

Figure 4 shows the chromatograms by HPLC-DAD after the application of the best degradation conditions. The chromatograms (a) shows the beginning of the experiment with and without $\mathrm{pH}$ adjustment, and with or without hydrogen peroxide addition and the chromatograms (b) shows the final of the experiment after 1, 3, 6 and $10 \mathrm{~min}$, its confirmation was carried out by comparison of the spectrum with the standard spectrum. This results were confirmed by LC-ESI-MS/MS analysis, by mass spectrum
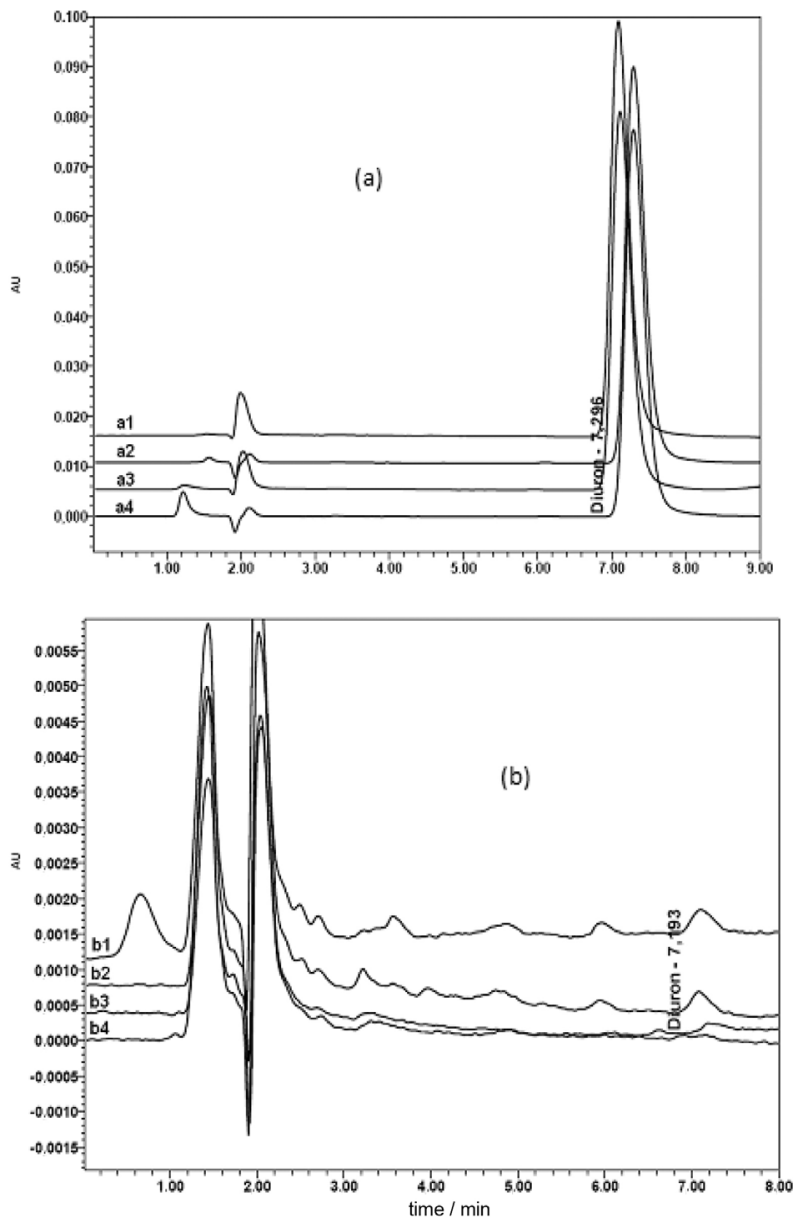

Figure 4. Chromatograms of diuron sample: (a) before the degradation: (a1) diuron solution $10 \mathrm{mg} \mathrm{L}^{-1}$; (a2) diuron solution plus $\mathrm{H}_{2} \mathrm{O}_{2}$; (a3) diuron solution in $\mathrm{pH} 2.5$; (a4) diuron solution plus $\mathrm{H}_{2} \mathrm{O}_{2}$ in $\mathrm{pH} 2.5$; (b) after the degradation experiment: (b1) after $1 \mathrm{~min}$; (b2) after $3 \mathrm{~min}$; (b3) after $6 \mathrm{~min}$ and (b4) after $10 \mathrm{~min}$

confirmation and the authentic standard comparison, diuron and 3,4-DCA, the parent compound.

At the end of the treatment, TOC was reduced of 10.0 to $5.4 \mathrm{mg} \mathrm{L}^{-1}$ (Figure 5), which is in accordance with the requirements regarding receiving waters for effluents release issued by Brazilian laws. ${ }^{32}$

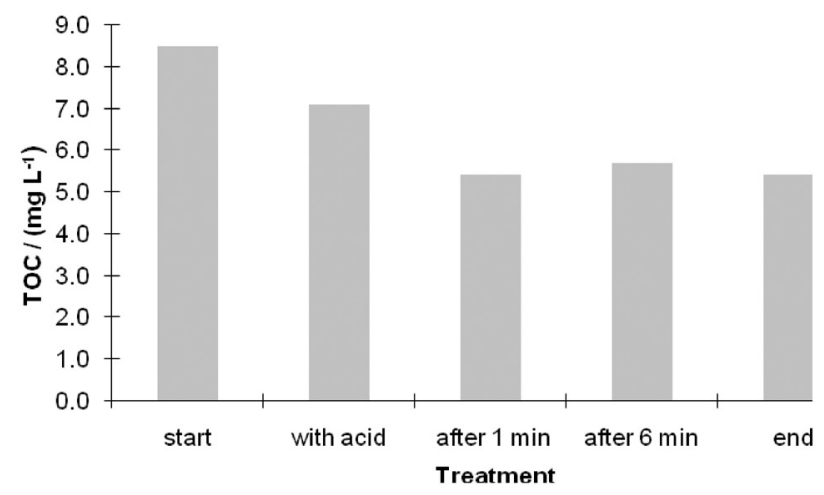

Figure 5. Total organic carbon concentration during treatment. 


\section{Conclusions}

The Fenton's reaction degradation of diuron in aqueous solution was investigated using $\mathrm{Fe}^{0} / \mathrm{H}_{2} \mathrm{O}_{2}$ system. The degradation was strongly affected by $\mathrm{pH}$, iron amount and $\mathrm{H}_{2} \mathrm{O}_{2}$ concentration. The best degradation condition was $\mathrm{pH} 2.5,2 \mathrm{~g}$ of iron and $2 \mathrm{mmol} \mathrm{L}^{-1} \mathrm{H}_{2} \mathrm{O}_{2}$. At the end of the treatment, total organic carbon was reduced.

The advantages of $\mathrm{Fe}^{0} / \mathrm{H}_{2} \mathrm{O}_{2}$ system are the rapid degradation (up to $10 \mathrm{~min}$ ), high efficiency (higher than 99\%), simple handling and cheap method which can be applied to treat contaminated environments and agricultural waste, especially in the laundering of pesticide packaging. This method can be even used by small farmers was a new methodology for reducing levels of diuron and other pesticides.

\section{Acknowledgments}

This study has been funded by FAPERGS and CNPq.

\section{References}

1. Vischetti, C.; Capri, E.; Perucci, P.; Trevisan, M.; Casucci, C.; Chemosphere 2004, 55, 823; Acero, J. L.; Benítez, F. J.; Real, F. J.; González, M.; J. Hazard. Mater. 2008, 153, 320.

2. Macounová, K.; Krýsová, H.; Ludvýk, J.; Jirkovský, J.; J. Photochem. Photobiol., A 2003, 156, 273.

3. Giacomazzi, S.; Cochet, N.; Chemosphere 2004, 56, 1021.

4. Thomas, K.; Fileman, T. W.; Readman, J. W.; Waldock, M. E. J.; Mar. Pollut. Bull. 2001, 42, 677.

5. Okamura, H.; Aoyama, I.; Ono, Y.; Nishida, T.; Mar. Pollut. Bull. 2003, 47, 59.

6. Guérita, G.; Bocquené, A.; James, A.; Thybaud, E.; Minier, C.; Ecotoxicol. Environ. Saf. 2008, 71, 291.

7. Dahl, B.; Blanck, H.; Mar. Pollut. Bull. 1996, 32, 342; Boxall, A. B. A.; Comber, S. D.; Conrad, A. U.; Howcroft, J.; Zaman, N.; Mar. Pollut. Bull. 2000, 11, 898; Martinez, K.; Ferrer, I.; Hernando, M. D.; Fernandez, A. R.; Marce, R. M.; Borrull, F.; Barcelo, D.; Environ. Technol. 2001, 22, 543.

8. Thomas, K. V.; Black, S. J.; Waldock, M. J.; Mar. Pollut. Bull. 2000, 40, 739; Carbo, L.; Souza, V.; Dores, E. F. G. C.; Ribeiro, M. L.; J. Braz. Chem. Soc. 2008, 19, 1111.

9. Barceló, D.; Hennion, M. C.; Trace Determination of Pesticides and their Degradation Products in Water, $1^{\text {st }}$ ed., Elsevier: Amsterdam, 1997.

10. Tomlin, C. D. S.; The e-Pesticide Manual, $13^{\text {th }}$ ed. Version 3.0. Bcpc Publications Sales: London. 2003-2004.

11. Salvestrini, S.; Di Cerbo, P.; Capasso, S.; Chemosphere 2008, 48, 69.

12. Silva, C. M. M. S.; Fay, E. F.; Agrotóxicos e Ambiente. 1a. ed. Embrapa: Brasília, Brasil, 2004.
13. Zhou, T.; Li, Y.; Ji, J.; Wong, F.; Lu, X.; Sep. Purif. Technol. 2008, $62,551$.

14. Bremner, D. H.; Burgess, A. E.; Houllemare, D.; Namkung, K. C.; Appl. Catal., B 2006, 63, 15.

15. Tiburtius, E. R. L.; Peralta-Zamora, P.; Emmel, A.; Leal, E. S.; Quim. Nova 2005, 28, 61; Perez, M., Torrades, F.; Garcia-Hortal, J. A.; Domenech, X.; Peral, J.; Appl. Catal., B 2002, 36, 63; Oliveros, E.; Legrini, O.; Hohl, M.; Homas, M.; Braun, A.; Chem. Eng. Process. 1997, 36, 397.

16. Lapertot, M.; Ebrahimi, S.; Dazio, S.; Rubinelli, A.; Pulgarin, C.; J. Photochem. Photobiol., A 2007, 186, 34.

17. Urzedo, A. P. F. M.; Nascentes, C. C.; Augusti, R.; J. Braz. Chem. Soc. 2009, 20, 51.

18. Pereira, W. S.; Freire, R. S.; Quim. Nova 2005, 28, 130.

19. Arruda, T. L.; Jardim, W.; Quim. Nova 2007, 30, 1628.

20. Barreiro, J. C.; Capelato, M. D.; Martin-Neto, L. C.; Hansen, H. C. B.; Water Res. 2007, 41, 55.

21. Farré, M. J.; Brosillon, S.; Doménech, X.; Peral, J.; J. Photochem. Photobiol., A 2007, 189, 364.

22. Gooddy, D. C.; Chilton, P.J.; Harrison, I.; Sci. Total Environ. 2002, 297, 67; Sorensen, S. R.; Bending, G. D.; Jacobsen, C. S.; Walker, A.; Aamand, J.; FEMS Microbiol. Ecol. 2003, 45, 1; Cederlund, H.; Borjesson, E.; Onneby, K.; Stenstrom, J.; Soil Biol. Biochem. 2007, 39, 473.

23. Joo, S. H.; Feitz, A. J.; Sedlak, D. L.; Waite, T. D.; Environ. Sci. Technol. 2005, 39, 1263.

24. Bratsch, S. G.; J. Phys. Chem. Ref. Data 1989, $18,1$.

25. Freire, R. S.; Pereira, W. S.; J. Braz. Chem. Soc. 2006, 17, 832.

26. Klausen, J.; Ranke, J.; Schwarzenbach, R. P.; Chemosphere 2001, $44,511$.

27. Satapanajaru, T.; Comfort, S. D.; Shea, P. J.; J. Environ. Qual. 2003, 32, 1726.

28. Roy, G.; DeDonato, P.; Gorner, T.; Barres, O.; Water Res. 2003, 37, 4954.

29. Scherer, M. M.; Johnson, K. M.; Westall, J. C.; Tratnyek, P. G.; Environ. Sci. Technol. 2001, 35, 2804.

30. Rima, J.; Aoun, E.; Hanna, K.; Li, Q. X.; J. Phys. IV France 2005, 124, 81.

31. Scherer, M. M.; Westall, J. C.; Ziomek-Moroz, M.; Tratnyek, P. G.; Environ. Sci. Technol. 1997, 31, 2385.

32. Ministério do Meio Ambiente. Conselho Nacional do Meio Ambiente (CONAMA). Resolução no 357, de 17 março de 2005. Classificação dos corpos de água e diretrizes ambientais para o seu enquadramento bem como estabelece condições e padrões de lançamento de efluentes. Diário Oficial da União, 18 março 2005. Ministry of Environment, National Council of Environment, Brazil, available at http:, line //www.mma.gov.br/port/conama/res/res05/ res35705.pdf.

Submitted: April 23, 2010

Published online: August 31, 2010 